\title{
Treatment of experimentally induced diabetic wound infected with methicillin-resistant Staphylococcus aureus using Aloe vera, Apium graveolens, and Sauropus androgynus extracts in rats
}

\author{
Yos Adi Prakoso ${ }^{1,2}$, Kurniasih Kurniasih ${ }^{3}$, Agustina Dwi Wijayanti ${ }^{4}$ and Yuli Purwandari Kristianingrum ${ }^{3}$
}

1. Doctoral Program in Veterinary Science, Faculty of Veterinary Medicine, University of Gadjah Mada, Yogyakarta 55281 Indonesia; 2. Faculty of Veterinary Medicine, University of Wijaya Kusuma Surabaya, East Java 60225, Indonesia;

3. Department of Pathology, Faculty of Veterinary Medicine, University of Gadjah Mada, Yogyakarta 55281, Indonesia; 4. Department of Pharmacology, Faculty of Veterinary Medicine, University of Gadjah Mada, Yogyakarta, 55281, Indonesia.

Corresponding author: Kurniasih Kurniasih, e-mail: kurniasih_1951@yahoo.co.id

Co-authors: YAP: yos.vet.docter@gmail.com, ADW: tinabdy@ugm.ac.id, YPK: yulipurwandari@ugm.ac.id

Received: 23-07-2019, Accepted: 13-11-2019, Published online: 23-12-2019

doi: www.doi.org/10.14202/IJOH.2019.99-106 How to cite this article: Prakoso YA, Kurniasih K, Wijayanti AD, Kristianingrum YP (2019) Treatment of experimentally induced diabetic wound infected with methicillin-resistant Staphylococcus aureus using Aloe vera, Apium graveolens, and Sauropus androgynus extracts in rats. Int J One Health 2019;5:99-106.

\begin{abstract}
Background and Aim: One of the complications of diabetes mellitus is diabetic ulcer. Diabetic ulcer is commonly infected by infectious agents, especially methicillin-resistant Staphylococcus aureus (MRSA). This study aimed to evaluate the potential effects of alcoholic extracts of Aloe vera, Apium graveolens, and Sauropus androgynus on promoting wound healing in a diabetic wound infected with MRSA.

Materials and Methods: A total of 60 male Sprague-Dawley rats (6 months old, weighing 250-300 g) were injected with $65 \mathrm{mg} / \mathrm{kg}$ body weight of streptozotocin to induce diabetes. On day 7, the backs of the rats were shaved, and two circular wounds ( $4 \mathrm{~mm}$ in diameter) were created on their back, which were infected with MRSA. The rats were divided into six groups: Group I = control, Group II = treated with cream base without extract, Group III = treated with $2 \% \mathrm{~A}$. vera cream, Group IV = treated with $2 \%$ A. graveolens cream, Group V = treated with $2 \%$. androgynus cream, and Group VI = treated with $2 \%$ A. vera $+2 \%$ A. graveolens $+2 \%$ S. androgynus cream. The wounds were treated twice a day for 14 days. The data were collected on days 7 and 14 .
\end{abstract}

Results: The results showed that all three herbal extracts and their combination decreased wound area and percentage of the wound, increased tensile strength of skin, collagen deposition, vascular endothelial growth factor expression, and skin thickness, and depressed the C-reactive protein profile and cyclooxygenase- 2 expression.

Conclusion: A. vera, A. graveolens, and S. androgynus creams can be used as herbal therapies against diabetic wounds infected with MRSA, both as a single and combination treatment.

Keywords: Aloe vera, Apium graveolens, diabetes ulcer, methicillin-resistant Staphylococcus aureus, Sauropus androgynus.

\section{Introduction}

Diabetes mellitus (DM) in humans is also known as a silent killer. It has the highest prevalence in the world [1]. Pathophysiologically, DM is caused by the destruction of beta-pancreatic cells, which leads to a decrease in insulin synthesis [2]. The decrease in insulin impairs the metabolism of whole-body cells [3], including skin cells [4]. Further, it can impair the regeneration of skin cells in both normal and pathological conditions. Thus, injuries in DM patients commonly become chronic, leading to diabetic ulcers [5]. Diabetic ulcer facilitates colonization of bacteria, such as Staphylococcus aureus, to form biofilms on the wound area [6]. S. aureus infection can become

Copyright: Prakoso, et al. This article is an open access article distributed under the terms of the Creative Commons Attribution 4.0 International License (http://creativecommons.org/licenses/ by/4.0/), which permits unrestricted use, distribution, and reproduction in any medium, provided you give appropriate credit to the original author(s) and the source, provide a link to the Creative Commons license, and indicate if changes were made. The Creative Commons Public Domain Dedication waiver (http:// creativecommons.org/ publicdomain/zero/1.0/) applies to the data made available in this article, unless otherwise stated. more serious if it is resistant to antibiotics such as methicillin; $S$. aureus resistant to methicillin is termed as methicillin-resistant $S$. aureus (MRSA) [7]. In addition, MRSA infection on diabetic wounds increases the financial burden. The inhibition of colonization with MRSA biofilm is an effective procedure to prevent further infection and increase wound healing activity [8]. However, the utilization of antibiotics is not recommended because it can generate severe resistance profiles. Natural antioxidants and antibacterial compounds used in herbal remedies are known to be efficient in treating infected wounds.

Most herbal remedies consist of phenolic compounds that are potential of natural antioxidants [9]. These antioxidants, on topical application, inhibit the oxidative effects in the skin due to reactive oxygen species (ROS) and increase the local cellular immune response [10]. Aloe vera, Apium graveolens, and Sauropus androgynus are commonly used as traditional medicines in Indonesia.

A. vera contains several bioactive compounds such as tannin, saponin, flavonoid, and alkaloid [11]. 
Indonesians use $A$. vera to treat digestive disorders. A previous study reported that $A$. vera has a beneficial constituent, which acts as an anti-inflammatory agent activating cluster of differentiation (CD4+) and CD8+ lymphocytes on wound tissue [12]. In the pharmaceutical industry, $A$. vera has been synthesized for its antioxidant, antifungal [13], and antibiotic properties [14]. S. androgynus has similar antioxidant compounds, and it is commonly used as an antioxidant and antitoxic and to prevent ROS production [15]. The utilization of $S$. androgynus as the feed additive in a broiler increases the immune expression of CD4+/CD8+ lymphocytes that help depress cellular destruction during aflatoxicosis [16]. Similar to the others, A. graveolens is used as an antifungal agent [17], an anti-carcinogenic agent for the treatment of lymphoblastic leukemia, and a radical scavenging agent [18].

Thus, a therapeutic approach for diabetic wounds infected with MRSA using $A$. vera, $A$. graveolens, and $S$. androgynus is necessary to be elucidated, not only for the complementary therapy but also to increase the value of those herbals in pharmaceutical industries.

\section{Materials and Methods}

\section{Ethical approval}

All the animal protocols were approved and monitored by the Ethical Clearance Committee of Faculty of Veterinary Medicine, University of Gadjah Mada, Yogyakarta, Indonesia (approval number: 0046/EC-FKH/Int/2019). The experiments were conducted at the Integrated Laboratory, Faculty of Health, University of Muhammadiyah Sidoarjo, East Java, Indonesia, and Department of Pathology, Faculty of Veterinary Medicine, University of Gadjah Mada, Yogyakarta, Indonesia.

\section{Herbal preparations}

Herbal specimens were collected from a botanical market in Batu, Malang, East Java, Indonesia. Herbal species were identified at the Plant Conservation Center, Botanical Garden of Purwodadi, Indonesian Institute of Sciences and deposited with the voucher number: 0276, 0277, and 0278/IPH.06/HM/II/2019.

\section{Extraction of A. vera, A. graveolens, and S. androgynus}

The herbal specimens were dried in an oven at $80^{\circ} \mathrm{C}$ for $1 \mathrm{~h}$. The dried herbals were macerated using $70 \%$ alcohol (one part of dried herbal: Four parts of $70 \%$ alcohol) and then evaporated using an evaporator. The extracts were stored in a refrigerator at $4^{\circ} \mathrm{C}$ to maintain their stability until further use.

\section{Preliminary study}

The preliminary study was conducted using a minimum inhibitory concentration (MIC) test. The extract was tested against MRSA suspension using the microdilution technique. The concentration of the extract varied from $100 \%, 50 \%$, and $25 \%$, until it was $0 \%$ concentration. The mixture of MRSA suspension and the extracts were incubated at $37^{\circ} \mathrm{C}$ for $24 \mathrm{~h}$ using an incubator. After $24 \mathrm{~h}$, the absorbance values of the suspensions were measured using a spectrophotometer. The MIC of the extract that inhibits more than $50 \%$ bacterial growth was utilized in the preparation of the cream formulation in the in vitro study. Based on the preliminary study, it was concluded that $2 \%$ of the extract was the effective concentration against MRSA isolate in vitro, and this concentration was utilized in the cream base formulation.

\section{Cream base formulation}

The cream base contained stearic acid, potassium hydroxide, glycerin, methylparaben, propylparaben, and distilled water. The cream base was obtained by constantly stirring all ingredients at $70^{\circ} \mathrm{C}$ until homogenous. The extract was added to this cream base. This study utilized the $2 \%$ A vera cream, $2 \%$ A. graveolens cream, 2\% S. androgynus cream, and the combinations of $2 \%$ A. vera $+2 \%$ A. graveolens + $2 \% S$. androgynus cream.

\section{MRSA isolate}

The MRSA isolate was obtained from the Department of Microbiology, Faculty of Medicine, the University of Airlangga Surabaya, with authentication number: 53/UN3.1.1/MK/LL/2019. The MRSA isolate was enriched using Staphylococcus agar. The Staphylococcus agar was made by mixing 75 g sodium chloride, $10 \mathrm{~g}$ casein peptone, $5 \mathrm{~g}$ dipotassium phosphate, $2 \mathrm{~g}$ lactose, $30 \mathrm{~g}$ gelatin, $10 \mathrm{~g}$ D-mannitol, $2.5 \mathrm{~g}$ yeast extract, $15 \mathrm{~g}$ agar, and $1 \mathrm{~L}$ distilled water. The isolate was then transferred to broth media and incubated for $6 \mathrm{~h}$ until it showed turbidity of $0.5 \mathrm{McFarland}$.

\section{Animal models and experimental design}

A total of 60 male Sprague-Dawley rats (6 months old, weighing 250-300 g) were used. These rats were induced by the intraperitoneal injection of $65 \mathrm{mg} / \mathrm{kg}$ body weight of streptozotocin. The blood glucose level was monitored on days 3, 5, and 7 after induction. The Sprague-Dawley rats with a stable blood glucose level (more than $235 \mathrm{mg} / \mathrm{dL}$ ) were used as the DM animal models. On day 7, the backs of the diabetic Sprague-Dawley rats were shaved, and two circular wounds (4 $\mathrm{mm}$ in diameters) were created. The wounds were then infected with $30 \mu \mathrm{L}$ of MRSA isolate and covered with a silicone dressing to ensure the bacteria completely infected the tissue. These rats were divided into six groups and were treated as follows: Group I = control group without treatment; Group II = treated with cream base without extract; Group III = treated with $2 \%$ A. vera cream; Group IV $=2 \%$ A. graveolens cream; Group V $=2 \%$ $S$. androgynus cream; and Group VI $=2 \% A$. vera + $2 \%$ A. graveolens $+2 \% S$. androgynus cream. Before the treatment, the wounds were incubated for $24 \mathrm{~h}$. The treatment was conducted twice a day for 14 days.

\section{Blood collection}

Data were collected on days 7 and 14 after the treatment. Wound area, percentage of the wound area, C-reactive protein (CRP) value, and histopathology were determined. On day 7, a total of 30 SpragueDawley rats were euthanized using lethal doses of 
dissociative anesthetics $(150 \mathrm{mg} / \mathrm{kg}$ ketamine + $10 \mathrm{mg} / \mathrm{kg}$ of xylazine). Before euthanizing the rats, blood was collected from the tail vein. These blood samples were kept at room temperature until the serum was separated. The CRP value was measured following the method described in a previous study [19].

\section{Macroscopy and skin tensile strength}

After euthanizing the rats, the wound area was measured using a digital caliper. The wound area on the day (x) was measured using the formula diameter $_{1} \quad(\mathrm{~mm}) \times$ diameter $_{2} \quad(\mathrm{~mm}) . \quad$ The percentage of the wound area was counted using the formula:

$$
\begin{aligned}
& \text { Wound area } \\
& \text { Percentage wound area }(\%)=\frac{\text { day }(x)}{\text { Wound area }} \times 100 \\
& \text { day (0) }
\end{aligned}
$$

Further, the tensile strength of the skin was measured using a tensiometer. Two sides (left and right) of the wound were clamped using tissue clamps. Loads were then applied to the right side until the skin tissue was torn apart. The result is expressed in grams.

\section{Histopathology and immunohistochemistry}

The skin samples were collected and stored in $10 \%$ neutral buffered formalin for $24 \mathrm{~h}$. The skin was then processed for histopathology. The skin samples were dehydrated and cleared using graded alcohol and xylene. They were then embedded in paraffin blocks. The blocks were then cut using a microtome at $0.5 \mu \mathrm{m}$ thickness. Further, the tissues were stained using hematoxylin and eosin and Mallory's stain. The purpose of the staining was to express the tissue component and collagen deposition on the tissue. Immunohistochemistry analysis was performed on the tissue specimens using the antibody against vascular endothelial growth factor (VEGF) (Santa Cruz Biotechnology, Inc. VEGF (C-1): sc - 7269) and cyclooxygenase-2 (COX-2) (Santa Cruz Biotechnology, Inc. COX-2 (D-12): sc - 166475).

\section{Morphometry}

The histopathology and immunohistochemistry slides were analyzed by a single histopathologist. Further, the epidermal thickness, ratio thickness of the natural dermis on both sides of the wound, and immunohistochemistry were analyzed using ImageJ software (NIH, USA, Public Domain, BSD-2). However, the sections were scored based on the presence of fibroblasts, collagen deposition, and inflammatory cell infiltration using the following scoring system, $0=$ absent; $1=$ minimal; $2=$ mild; $3=$ moderate; and $4=$ severe.

\section{Statistical analysis}

The normally distributed and homogenous data were analyzed using a parametric test. The non-normal and non-homogeneous data were analyzed using a non-parametric test. Following these analyses, the wound area, percentage of the wound area, and CRP level were analyzed by two-way ANOVA and a post hoc test. However, histopathology results were analyzed using the Kruskal-Wallis test and the Mann-Whitney U-test. This study utilized $\mathrm{p} \leq 0.05$.

\section{Results \\ CRP level}

CRP is the main acute phase protein that influences inflammation. An increase in the level of CRP in the blood indicates systemic and local inflammation. The rats treated with $A$. vera, A. graveolens, and S. androgynus creams and their combination showed a lower CRP level than the untreated controls $(\mathrm{p} \leq 0.05)$. The CRP level in Groups I and II was higher than that in the herbal extract-treated groups, indicating that inflammation in Groups I and II was more severe than that in the other groups (Table-1). This finding shows that, as a topical treatment, A. vera, A. graveolens, and $S$. androgynus creams and their combination inhibited the local inflammation and infection on the wound tissue.

\section{Macroscopy}

The wound healing progress could be examined by the measurement of the wound's macroscopic appearance. The treated Groups III, IV, V, and VI showed similar wound healing. The wound area and percentage of wound area in Groups III, IV, V, and VI completely healed on day 14; however, Groups I and II did not show any healing $(\mathrm{p} \leq 0.05)$ as revealed by the larger wound areas in these groups $(\mathrm{p} \leq 0.05)$ (Table-2 and Figure-1).

Table-1: CRP level in the wound skin tissue of diabetes mellitus rats infected by methicillin-resistant Staphylococcus aureus.

\begin{tabular}{lccc}
\hline Parameter & Group & Day 7 & Day 14 \\
\hline CRP level & I & $88.60 \pm 7.95$ & $99.40 \pm 10.85$ \\
& II & $86.20 \pm 2.38$ & $97.20 \pm 4.86$ \\
& III & $49.80 \pm 2.86^{\mathrm{a}}$ & $47.80 \pm 4.14^{\mathrm{a}}$ \\
& IV & $50.40 \pm 6.18^{\mathrm{a}}$ & $50.00 \pm 5.70^{\mathrm{a}}$ \\
& V & $52.20 \pm 1.48^{\mathrm{a}}$ & $46.00 \pm 2.54^{\mathrm{a}}$ \\
& VI & $52.00 \pm 2.54^{\mathrm{a}}$ & $49.40 \pm 5.12^{\mathrm{a}}$ \\
\hline
\end{tabular}

$\overline{a, b, c, d}$ Different superscripts on the column show significance value $\mathrm{p} \leq 0.05$. $C R P=C$-reactive protein

Table-2: Macroscopic examination of the wound skin tissue of diabetes mellitus rats infected by methicillinresistant Staphylococcus aureus.

\begin{tabular}{lccc}
\hline Parameter & Group & Day 7 & Day 14 \\
\hline Wound area & I & $118.88 \pm 22.46$ & $504.02 \pm 76.81$ \\
& II & $105.99 \pm 14.62$ & $502.56 \pm 118.91$ \\
& III & $4.59 \pm 0.34^{\mathrm{a}}$ & $0.03 \pm 0.06^{\mathrm{a}}$ \\
& IV & $5.95 \pm 2.78^{\mathrm{a}}$ & $0 \pm 0^{\mathrm{a}}$ \\
& V & $4.67 \pm 1.68^{\mathrm{a}}$ & $0 \pm 0.01^{\mathrm{a}}$ \\
Percentage of & VI & $1.94 \pm 0.61^{\mathrm{a}}$ & $0 \pm 0^{\mathrm{a}}$ \\
wound area & II & $742.98 \pm 140.40$ & $3150.13 \pm 480.09$ \\
& III & $28.71 \pm 2.18^{\mathrm{a}}$ & $0.21 \pm 0.40^{\mathrm{a}}$ \\
& IV & $37.23 \pm 17.43^{\mathrm{a}}$ & $0.02 \pm 0.05^{\mathrm{a}}$ \\
& V & $29.22 \pm 10.51^{\mathrm{a}}$ & $0.06 \pm 0.08^{\mathrm{a}}$ \\
& VI & $12.13 \pm 3.85^{\mathrm{a}}$ & $0 \pm 0^{\mathrm{a}}$ \\
\hline
\end{tabular}

$a, b, c, d$ Different superscripts on the column show significance value $p \leq 0.05$ 


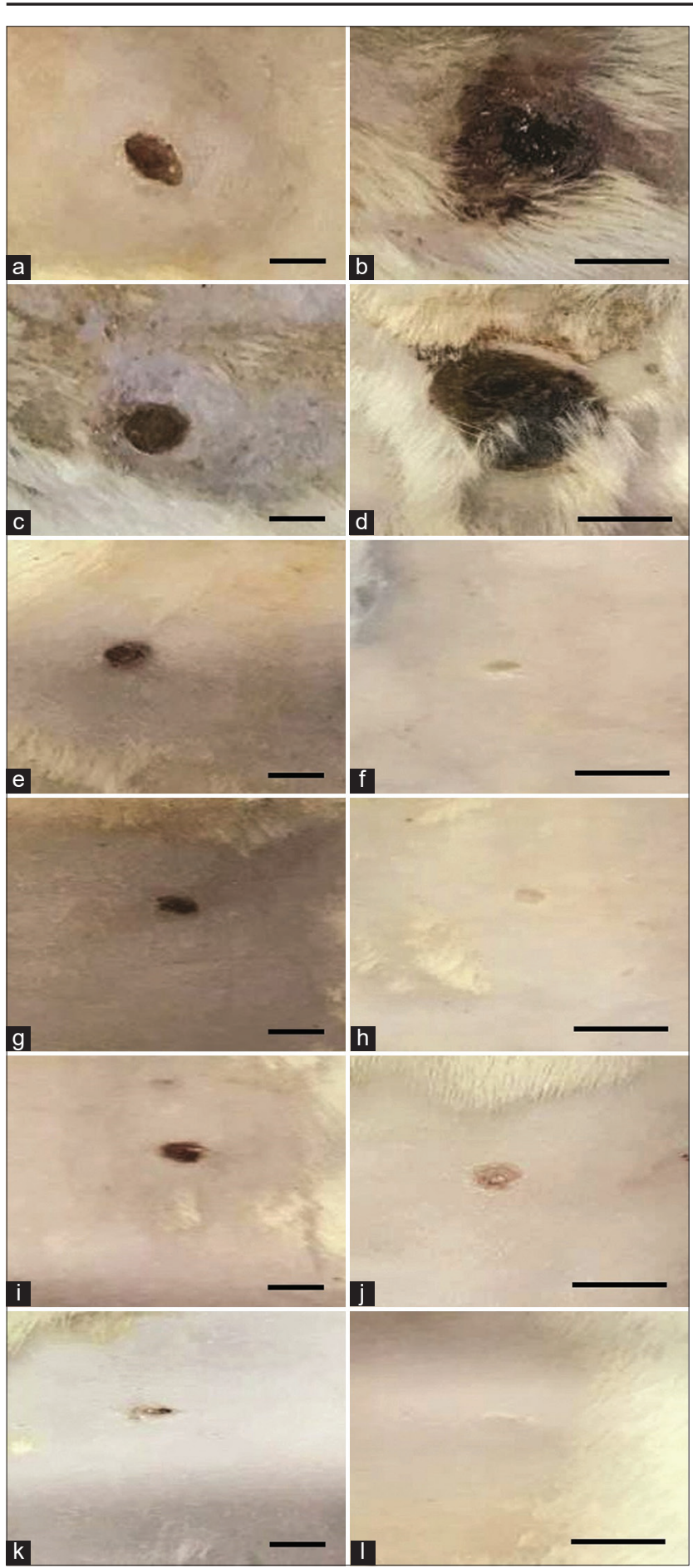

Figure-1: Macroscopic examination of the wound skin tissue of diabetes mellitus rats infected by methicillinresistant Staphylococcus aureus on days 7 and 14. Day 7 after treatment: The skin wound tissue of Group I with edema (a), Group II showed severe edema with a rash surrounding the wound area (c), Group III showed minimal wound area with scab (e) similar with that of Group IV (g), Group V (i), and Group VI (k); day 14 after treatment: The skin wound of Group I showed severe exudation with ulceration and large wound area (b), and it was similar to that in Group II (d), minimal wound area in Groups III (f), IV (h), V (j), and in Group VI (I). Scale bar: $1 \mathrm{~cm}$.

\section{Tensile strength of skin and collagen deposition}

Following the macroscopic examination, the tensile strength of skin was measured to analyze skin integrity. The tensile strength of the skin is associated with collagen deposition in the skin. The tensile strength of the skin in Groups III, IV, V, and VI was higher than that of the control group, $\mathrm{p}=0.00(\mathrm{p} \leq 0.05)$. The skin in Group VI (treated with a combination of $A$. vera, A. graveolens, and $S$. androgynus) was the highest, followed by that in Groups IV, III, V, and control. Collagen deposition was studied by Mallory staining. Group VI had higher collagen deposition than the others (Table-3). The control group showed severe hemorrhage in the dermal part; however, this was not observed in Groups II, III, IV, V, and VI (Figure-2).

\section{Histopathology}

The epidermal thickness in the treated Groups III, $\mathrm{IV}, \mathrm{V}$, and VI increased throughout the experimental period (on days 7 and 14). However, there was no increase in the epidermal in the control group. The thickness was greater in the combination treatment group than in the single treatment groups $(\mathrm{p} \leq 0.05)$. The combination treatment not only increased the epidermal thickness but also increased the thickness of the natural dermis and the number of fibroblasts and decreased inflammatory cell infiltration $(\mathrm{p} \leq 0.05)$ (Table-4). The histopathological images are shown in Figure-3.

\section{Immunohistochemistry}

VEGF and COX-2 are important factors that influence wound healing in both diabetic and non-diabetic healings. VEGF expression in the treated groups was higher than that in the control group $(p<0.05)$ (Table-5), indicating that the treatments have the potential to promote the expression of VEGF. Further, Group VI showed the highest VEGF expression. All treated groups showed a decrease in the level of COX-2 during the observation period $(\mathrm{p}<0.05)$; however, COX-2 level remained high in Groups I and II (Table-5). The increased expression of VEGF and the decreased expression of COX-2 in the wound area indicate that the treatments promoted healing. The expression levels of VEGF and COX-2 in the skin are shown in Figure-4.

\section{Discussion}

The incidence of DM-related amputation is more than $35.1 \%$ globally [20]. It is necessary to accelerate wound healing in DM patients. A. vera, A. graveolens, and $S$. androgynus contain antioxidant compounds, including phenols, which have the potential to scavenge hydroxyl radicals [21]. Hydroxyl radicals are produced by inflammation and can cause apoptosis. The highest apoptosis process in wounds in DM affects the matrix degradation that leads to chronic injury and inflammation [22].

Local inflammation in wound tissues alters the CRP serum profile of rats. CRP is used as a marker of systemic inflammation and vascular diseases, and infection. In DM patients, an increase in CRP level is related to the risk of mortality [23]. During infection, CRP profile increased significantly and its decreasing 
Available at www.onehealthjournal.org/Vol.5/15.pdf

Table-3: Skin tensile strength and collagen deposition.

\begin{tabular}{lccc}
\hline Parameter & Group & Day 7 & Day 14 \\
\hline Skin tensile & I & $13.68 \pm 3.43$ & $14.74 \pm 1.03$ \\
strength & II & $14.44 \pm 1.38$ & $15.42 \pm 0.55$ \\
& III & $136.64 \pm 11.82^{\mathrm{a}}$ & $483.86 \pm 3.16^{\mathrm{a}}$ \\
& IV & $133.98 \pm 3.44^{\mathrm{a}}$ & $510.52 \pm 7.36^{\mathrm{b}}$ \\
& V & $126.14 \pm 4.72^{\mathrm{a}}$ & $455.80 \pm 39.00^{\mathrm{c}}$ \\
Collagen & VI & $146.96 \pm 7.55^{\mathrm{a}}$ & $531.60 \pm 13.61^{\mathrm{d}}$ \\
deposition & I & $1.00 \pm 0$ & $1.00 \pm 0$ \\
& II & $1.00 \pm 0$ & $1.00 \pm 0$ \\
& III & $2.00 \pm 0^{\mathrm{a}}$ & $3.40 \pm 0^{\mathrm{a}}$ \\
& IV & $2.20 \pm 0.44^{\mathrm{a}}$ & $3.60 \pm 0.54^{\mathrm{a}}$ \\
& V & $2.00 \pm 0^{\mathrm{a}}$ & $3.40 \pm 0^{\mathrm{a}}$ \\
& VI & $3.00 \pm 0^{\mathrm{b}}$ & $4.00 \pm 0^{\mathrm{b}}$ \\
\hline
\end{tabular}

$\mathrm{a}, \mathrm{b}, \mathrm{c}, \mathrm{d}$ Different superscripts on the column show significance value $p \leq 0.05$

Table-4: Histopathology examination of the wound skin tissue of diabetes mellitus rats infected by methicillinresistant Staphylococcus aureus.

\begin{tabular}{|c|c|c|c|}
\hline Parameter & Group & Day 7 & Day 14 \\
\hline \multirow[t]{6}{*}{ Epidermal thickness } & $\mathrm{I}$ & $0 \pm 0$ & $0 \pm 0$ \\
\hline & II & $0 \pm 0$ & $0 \pm 0$ \\
\hline & III & $21.60 \pm 2.07^{a}$ & $55.50 \pm 2.40^{\mathrm{a}}$ \\
\hline & IV & $28.80 \pm 1.78^{b}$ & $60.00 \pm 1.58^{b}$ \\
\hline & $\mathrm{V}$ & $31.40 \pm 2.40^{c}$ & $52.40 \pm 2.19^{c}$ \\
\hline & VI & $34.60 \pm 2.40^{d}$ & $60.60 \pm 1.51^{d}$ \\
\hline Ratio thickness of & $\mathrm{I}$ & $0.17 \pm 0.01$ & $0.22 \pm 0.03$ \\
\hline the natural dermis & II & $0.16 \pm 0.00$ & $0.24 \pm 0.03$ \\
\hline on both sides of the & III & $0.35 \pm 0.01^{a}$ & $0.36 \pm 0.02^{a}$ \\
\hline \multirow[t]{3}{*}{ wound } & IV & $0.34 \pm 0.04^{a}$ & $0.34 \pm 0.06^{a}$ \\
\hline & $\mathrm{V}$ & $0.38 \pm 0.01^{a}$ & $0.38 \pm 0.01^{a}$ \\
\hline & VI & $0.40 \pm 0.02^{b}$ & $0.39 \pm 0.05^{b}$ \\
\hline \multirow[t]{6}{*}{ Fibroblast } & $\mathrm{I}$ & $1.00 \pm 0.70$ & $1.20 \pm 0.44$ \\
\hline & II & $1.00 \pm 0$ & $1.40 \pm 0.54$ \\
\hline & III & $2.20 \pm 0.44^{a}$ & $3.80 \pm 0.44^{a}$ \\
\hline & IV & $2.80 \pm 0.44^{a}$ & $3.80 \pm 0.44^{a}$ \\
\hline & $\mathrm{V}$ & $3.40 \pm 0.54^{a}$ & $3.60 \pm 0.54^{a}$ \\
\hline & VI & $3.60 \pm 0.54^{b}$ & $4.00 \pm 0^{\mathrm{b}}$ \\
\hline \multirow{6}{*}{$\begin{array}{l}\text { Inflammatory cell } \\
\text { infiltration }\end{array}$} & $\mathrm{I}$ & $4.00 \pm 0$ & $4.00 \pm 0$ \\
\hline & II & $4.00 \pm 0$ & $4.00 \pm 0$ \\
\hline & III & $2.80 \pm 0.44^{a}$ & $0.60 \pm 0.54^{a}$ \\
\hline & IV & $2.40 \pm 0.54^{b}$ & $0.40 \pm 0.54^{b}$ \\
\hline & $\mathrm{V}$ & $2.60 \pm 0.54^{c}$ & $1.60 \pm 0.54^{c}$ \\
\hline & VI & $1.60 \pm 0.54^{d}$ & $0.20 \pm 0.44^{\mathrm{d}}$ \\
\hline
\end{tabular}

$\mathrm{a}, \mathrm{b}, \mathrm{c}, \mathrm{d}$ Different superscripts on the column show significance value $\mathrm{p} \leq 0.05$

levels reflect a better prognosis [24]. A decrease in CRP level is closely related to the healing of cutaneous wounds [25]. The CRP level rises within an hour after injury, and it accumulates in necrotic and inflamed tissues. However, CRP level is not only related to inflammation but also to promigratory properties that support wound healing in the early stage and gradually decrease during tissue recovery [26]. The decrease in CRP levels observed in the treated Groups III, IV, $\mathrm{V}$, and VI might have been because of the phenolic compounds present in A. vera, A. graveolens, and $S$. androgynus extracts that act as the antioxidant, antibacterial, and anti-inflammatory agents. The control group showed a high CRP level because of the increased necrotic and inflamed wound area.

Histopathological examination of the DM wound infected with MRSA showed the appearance of severe
Table-5: VEGF and COX-2 immunohistochemistry of the wound skin tissue of diabetes mellitus rats infected by methicillin-resistant Staphylococcus aureus.

\begin{tabular}{lccc}
\hline Parameters & Group & Day 7 & Day 14 \\
\hline VEGF & I & $7.72 \pm 2.67$ & $6.86 \pm 2.51$ \\
& II & $9.78 \pm 1.77$ & $8.66 \pm 2.45$ \\
& III & $16.00 \pm 1.96^{\mathrm{a}}$ & $21.14 \pm 1.46^{\mathrm{a}}$ \\
& IV & $16.32 \pm 2.15^{\mathrm{b}}$ & $26.97 \pm 1.84^{\mathrm{b}}$ \\
& V & $13.48 \pm 3.25^{\mathrm{a}}$ & $23.16 \pm 1.75^{\mathrm{a}}$ \\
$\mathrm{COX}-2$ & VI & $22.58 \pm 1.56^{\mathrm{c}}$ & $28.51 \pm 1.63^{\mathrm{c}}$ \\
& I & $29.01 \pm 0.81$ & $35.49 \pm 3.44$ \\
& II & $27.87 \pm 1.23$ & $38.65 \pm 5.65$ \\
& III & $18.30 \pm 0.90^{\mathrm{a}}$ & $3.86 \pm 0.82^{\mathrm{a}}$ \\
& IV & $14.70 \pm 2.05^{\mathrm{b}}$ & $2.04 \pm 0.31^{\mathrm{b}}$ \\
& V & $16.88 \pm 1.35^{\mathrm{a}}$ & $3.90 \pm 0.83^{\mathrm{a}}$ \\
& VI & $10.39 \pm 0.69^{\mathrm{c}}$ & $0.82 \pm 0.74^{\mathrm{c}}$ \\
\hline
\end{tabular}

$\overline{a, b, c, d \text { Different superscripts on the column show significance }}$ value $p \leq 0.05$. VEGF=Vascular endothelial growth factor, COX-2=Cyclooxygenase -2

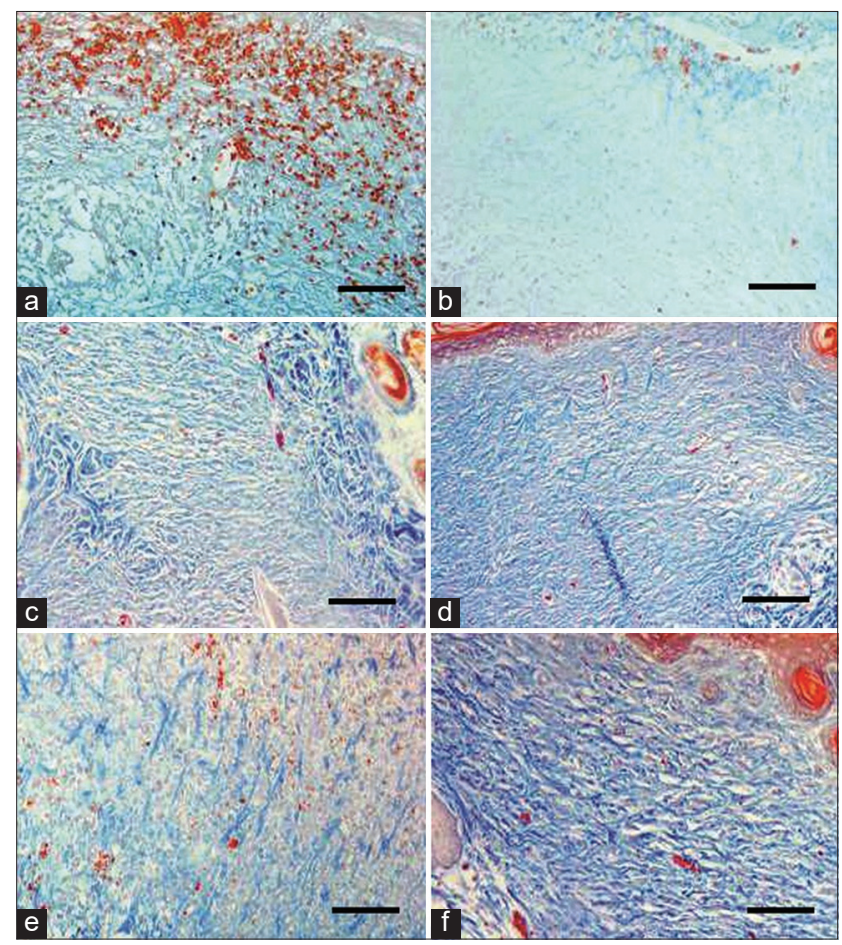

Figure-2: The collagen deposition of diabetic Sprague-Dawley rat skin wound infected with methicillinresistant Staphylococcus aureus on day 14 . Severe hemorrhage with mild collagen matrix in Group I (a); minimal collagen matrix in Group II (b); moderate new collagen deposition in Groups III (c) and IV (d); minimal collagen deposition in Group $\mathrm{V}(\mathrm{e})$; profound mature collagen in Group VI (f). Old collagen fibers stained deep blue, new collagen fibers stained light blue, and erythrocytes stained red. Mallory staining, $400 \times(a$ and $b)$; $200 \times(c-f)$. Scale bar: $50 \mu \mathrm{m}$ (a and b); $100 \mu \mathrm{m}$ (c-f).

inflammation dominated by neutrophil infiltration, indicating local oxidation that supports wound healing in the early stage but is detrimental at later stages [27]. Neutrophils prevent bacterial colonization and release several enzymes such as COX-1 and COX-2 that promote prostaglandin synthesis [28]. COX-2 is the primary protein that is expressed at the first stage of inflammation, and in contrast to the inhibition of COX-2, it increases the aggregation of platelets and 


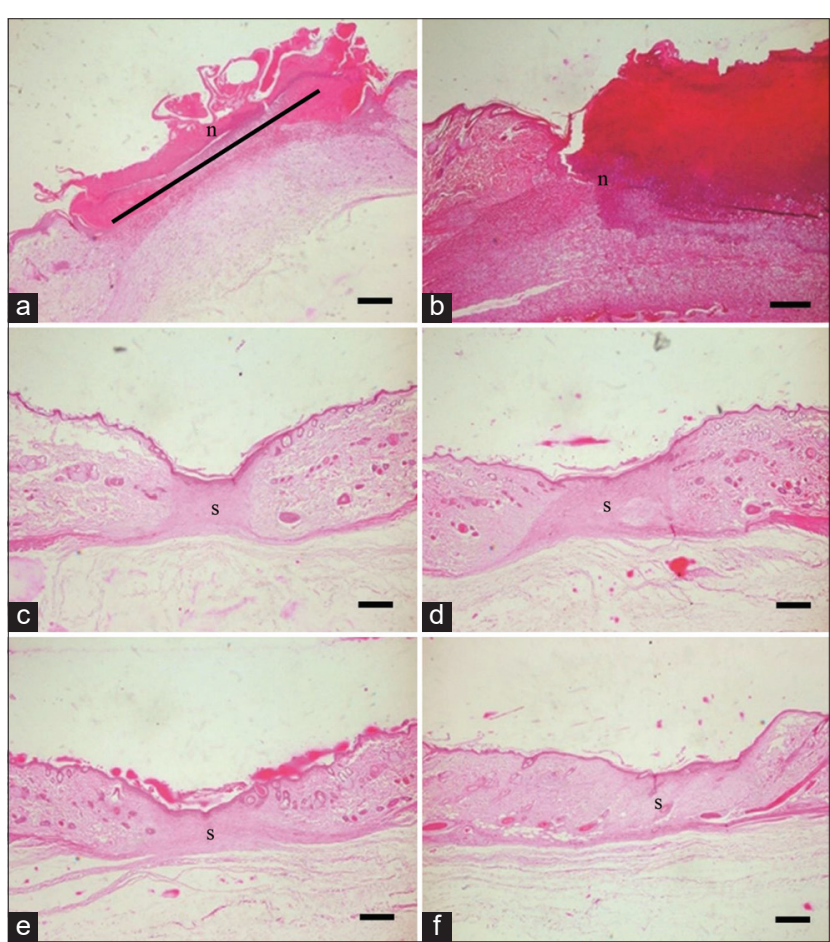

Figure-3: Histopathological change of Sprague-Dawley rats' diabetic wound infected with methicillin-resistant Staphylococcus aureus on day 14 after treatment. Large wound gaps (line) with severe necrosis ( $n$ ) in Group I (a) and Group II (b); skin wound with a complete architecture (s) on the Group III (c); Group IV (d); Group V (e); and Group VI (f). Hematoxylin and eosin, 4x (a and c-f); $100 \times(b)$. Scale bar: $100 \mu \mathrm{m}(a-f)$.

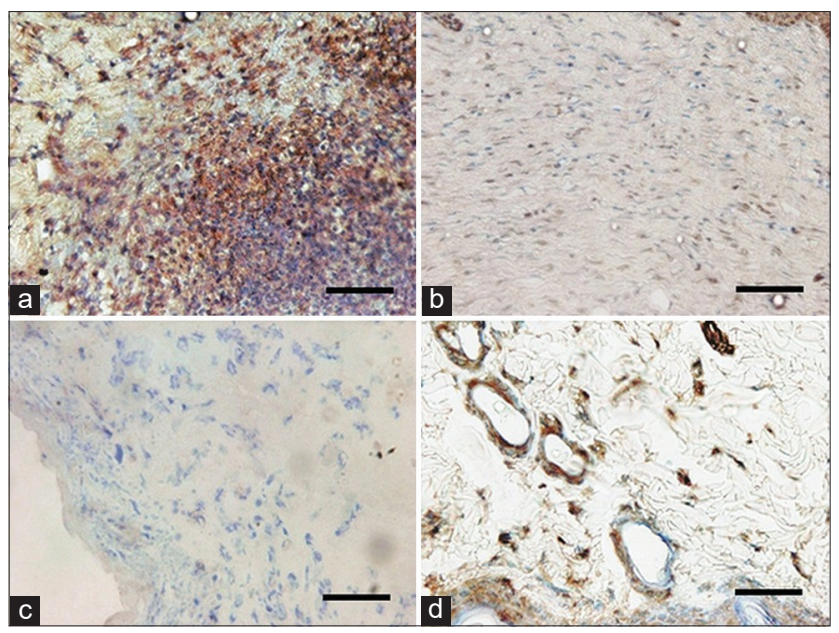

Figure-4: The immune-expression of vascular endothelial growth factor (VEGF) and cyclooxygenase-2 (COX-2) of diabetic wound Sprague-Dawley rats infected with methicillin-resistant Staphylococcus aureus on day 14 after treatment. There is no expression of the VEGF on the wound matrix in Group I (a); the VEGF was expressed on the pericytes of blood vessel on tissue matrix in Group VI (b); high expression of COX-2 on tissue matrix in Group I (c); low expression of COX-2 on wound tissue in Group VI (d). The positive reaction was indicated by the brown color of the DAB (arrow). Immunohistochemistry (IHC), antibody anti-VEGF, 200x ( $a$ and b); IHC, antibody antiCOX-2, 200x (c and d). Scale bar: $100 \mu \mathrm{m}(\mathrm{a}-\mathrm{d})$.

supports the proliferation and maturation of extracellular matrix (ECM) [29]. The inhibition of COX-2 in cutaneous wounds improves the healing through the inhibition of iNOS expression [30]. Tissues of rats treated with $A$. vera and $A$. graveolens showed better histology and COX-2 expression than those of the control and S. androgynus-treated rats. However, the combination of these three herb extracts showed a synergistic effect.

The topical application of these herb extracts in a cream-based formulation decreased the local oxidation at the site of skin injuries. A. vera, A graveolens, and $S$. androgynus creams increased skin integrity by promoting collagen deposition in the wound matrix and increasing the skin tensile strength. The collagen deposition on the wound area is facilitated by the formation of new blood vessels [31]. The new blood vessels influence the vascularization of the local skin that mediates oxygenation, nutrient supply, and the cells migration/infiltration so that the healing increases concomitantly. The high vascularization is identified by the appearance of VEGF in scar tissues. VEGF is a prominent pro-angiogenic factor for wound healing that facilitates the cells to migrate to the wound area [32]. The high expression of VEGF leads to tissue repair and re-arrangement of the ECM. The treated groups showed higher VEGF expression than the control $(p<0.05)$. The combination treatment group showed the highest VEGF expression.

During the healing of the wound infection, the utilizations of the antioxidant compound and antibacterial agents in the first stage of therapy support the destruction of infectious bacteria [33]. These mechanisms cause the minimal respond of inflammation but effective against injury. However, a minimal inflammatory response is caused by the radical scavenging activity of the antioxidant; this is effective because it directly acts on the side of wound infection. The minimum inflammatory response still consistently activates other healing factors such as fibroblast to proliferate and growth factors to increase recovery concomitantly without going through another phase. Short inflammation period minimalizes the synthesis of several enzymes such as COX-2 that inhibit the healing [34], and it potentially affects the tissue oxidation. Minimal stress oxidation triggers the synthesis of growth factor including VEGF that supports tissue oxygenation and provides nutrition to the fibroblast to proliferate and synthesize collagen to establish the ECM. The results also showed the better re-arrangement of the collagen matrix in the treated Groups III, IV, V, and VI compared to that of the control. As the synthesis product of fibroblast, the collagen compiles the matrix with high density and increase the tensile strength of the skin [35]. This result is similar to that of a previous study, which described that better collagen deposition increased the tensile strength of the skin [36]. Further, collagen deposition influences the ratio of thickness of natural dermis with the scar tissue; higher collagen deposition affects the increasing thickness of the scar tissue. Another observation showed that utilization of herb extracts in this study increased the epidermal 
thickness - the epidermis potential as the water barrier and another invasive disturbance. The epidermal thickness on the treated groups increases conformable with the observation periods, however not regarding the control group. These results reflected that the herbal cream therapies were effective against the epidermal thickness due to its antioxidant compounds [37].

All these microscopical mechanisms were reflected in the appearance of the skin wound in the treated groups. This study showed that the microscopic examination of the healing skin wound of the DM rat was synergistic with its macroscopic condition. The wound on the skin of the DM rats showed that there was no progress in healing because the DM condition impaired the cellular and immune responses [38]. Further, the DM condition is quite contradictive and its impact on the inflammation process, such as promoting the high synthesis of COX-2 on the wound tissue. In DM, COX-2 can be termed as the double-edged sword. In the advance mechanism, it impacts the regulation of cell proliferation and maturation through its oxidative pathways.

\section{Conclusion}

The cream formulations of the extracts of $A$. vera, A. graveolens, and $S$. androgynus and their combination promote wound healing in DM rats due to their antioxidant effect, ability to decrease inflammatory cell infiltration, and expression of VEGF in the wound area. They also decrease CRP level and COX-2 production, increase the number of fibroblasts, collagen deposition, tensile strength of the skin, epidermal and dermal thickness, thereby promoting wound healing.

\section{Authors' Contributions}

YAP, KK, ADW, and YPK designed the research. YAP analyzed the data and interpretation. YAP, KK, and ADW performed the research. YAP, KK, ADW, and YPK collaborated during the writing and revising of the manuscripts and approved the manuscript's final version. All authors read and approved the final manuscript.

\section{Acknowledgments}

This work was funded by Rekognisi Tugas Akhir (RTA) of the University of Gadjah Mada, Yogyakarta, Indonesia, with grant number 47/RTA/UGM 2019. The authors want to acknowledge all the laboratory technicians from Integrated Laboratory, Faculty of Health, University of Muhammadiyah Sidoarjo for their assistance.

\section{Competing Interests} interests.

The authors declare that they have no competing

\section{Publisher's Note}

Veterinary World (Publisher of International Journal of One Health) remains neutral with regard to jurisdictional claims in published institutional affiliation.

\section{References}

1. Shaw JE, Sicree RA, Zimmet PZ. Global estimates of the prevalence of diabetes for 2010 and 2030. Diabetes Res Clin Pract 2010;87:4-14.

2. Petersen MC, Vatner DF, Shulman GI. Regulation of hepatic glucose metabolism in health and disease. Nat Rev Endocrinol 2017;13:572-87.

3. Ndisang JF, Vannacci A, Rastogi S. Insulin resistance, Type 1 and Type 2 diabetes, and related complications 2017. J Diabetes Res 2017;2017:1478294.

4. Zubair M, Malik A, Ahmad J. Diabetic foot ulcer: A review. Am J Intern Med 2015;3:28-49.

5. Pendsey SP. Understanding diabetic foot. Int J Diabetes Dev Ctries 2010;30:75-9.

6. Lebeaux D, Ghigo JM. Management of biofilm-associated infections: What can we expect from recent research on biofilm lifestyles?. Med Sci (Paris) 2012;28:727-39.

7. Carroll KC. Rapid diagnostics for methicillin-resistant Staphylococcus aureus: Current status. Mol Diagn Ther 2008; 12:15-24.

8. Prakoso YA, Setiyo Rini C, Wirjaatmadja R. Efficacy of Aloe vera Ananas comosus and Sansevieria masoniana cream on the skin wound infected with MRSA. Adv Pharmacol Sci 2018;2018:4670569.

9. Boots AW, Haenen GR, Bast A. Health effects of quercetin: From antioxidant to nutraceutical. Eur J Pharmacol 2008;585:325-37.

10. Mhalla D, Zouari Bouassida K, Chawech R, Bouaziz A, Makni S, Jlaiel L, et al. Antioxidant, hepatoprotective, and anti-depression effects of Rumex tingitanus extracts and identification of a novel bioactive compound. Biomed Res Int 2018;2018:7295848.

11. Patel DK, Patel K, Dhanabal SP. Phytochemical standardization of Aloe vera extract by HPTLC techniques. J Acute Dis 2012;1:47-50.

12. Prakoso YA, Kurniasih. The effects of Aloe vera cream on the expression of $\mathrm{CD}^{+}$and $\mathrm{CD} 8^{+}$lymphocytes in skin wound healing. J Trop Med 2018;2018:6218303.

13. Medda S, Hajra A, Dey U, Bose P, Mondal NK. Biosynthesis of silver nanoparticles from Aloe vera leaf extract and antifungal activity against Rhizopus sp. and Aspergillus sp. Appl Nanosci 2015;5:875-80.

14. Parthasarathy G, Saroja M, Venkatachalam M, Gowthaman P, Evanjelene VK. Synthesis of nanoparticles from Aloe vera extract review paper. Int J Intercult Relat 2016;2:1570-5.

15. Prabhu A, Madhushree M, Devasya RP. Phytochemical constituents and antioxidants activities of some plants commonly used in India traditional diet. J Appl Pharm Sci 2015;11:108-12.

16. Prakoso YA, Puspitasari, Rini CS, Aliviameita A, Salasia SIO, Kurniasih, et al. The role of Sauropus androgynus (L.) Merr. leaf powder in the broiler chickens fed a diet naturally contaminated with aflatoxin. J Toxicol 2018;2018:2069073.

17. Roy K, Sarkar CK, Ghosh CK. Apium graveolens leaf extract-mediated synthesis of silver nanoparticles and its activity on pathogenic fungi. Dig J Nanomater Bios 2015; 10:393-400.

18. Kooti W, Daraei N. A review of the antioxidant activity of celery (Apium graveolens L). J Evid Based Complement Altern Med 2017;22:1029-34.

19. Kanaparthy A, Kanaparthy R, Niranjan N. Evaluation of serum C-reactive protein levels in subjects with aggressive and chronic periodontitis and comparison with healthy controls. Dent Res J (Isfahan) 2012;9:261-5.

20. Rodrigues BT, Vangaveti VN, Malabu UH. Prevalence and risk factors for diabetic lower limb amputation: A clinic-based case control study. J Diabetes Res 2016;2016:5941957.

21. Lyngsie G, Krumina L, Tunlid A, Persson P. Generation of hydroxyl radicals from reactions between a dimethoxyhydroquinone and iron oxide nanoparticles. Sci Rep 2018;8:10834. 
22. Chen Y, Zheng Z, Wang J, Tang C, Khor S, Chen J, et al. Berberine suppresses apoptosis and extracellular matrix (ECM) degradation in nucleus pulposus cells and ameliorates disc degeneration in a rodent model. Int J Biol Sci 2018;14:682-92.

23. Sattar N, Hingorani AD. C-reactive protein and prognosis in diabetes: Getting to the heart of the matter. Diabetes 2009;58:798-9.

24. Sproston NR, Ashworth JJ. Role of C-reactive protein at sites of inflammation and infection. Front Immunol 2018;9:754.

25. Yadav E, Singh D, Yadav P, Verma A. Antioxidant and anti-inflammatory properties of Prosopis cineraria based phenolic rich ointment in wound healing. Biomed Pharmacother 2018;108:1572-83.

26. Braig D, Kaiser B, Thiele JR, Bannasch H, Peter K, Stark GB, et al. A conformational change of C-reactive protein in burn wounds unmasks its proinflammatory properties. Int Immunol 2014;26:467-78.

27. Rallis M, Kyriazi M, Papaioannou GT, Vistos A, Liakos S, Daskalaki S, et al. P-152 skin inflammation and oxidative stress. Free Radic Biol Med 2017;108:S70.

28. Futagami A, Ishizaki M, Fukuda Y, Kawana S, Yamanaka N. Wound healing involves induction of cyclooxygenase-2 expression in rat skin. Lab Invest 2002;82:1503-13.

29. Korbecki J, Baranowska-Bosiacka I, Gutowska I, Chlubek D. Cyclooxygenase pathways. Acta Biochim Pol 2014;61:639-49.

30. Romana-Souza B, Santos JS, Bandeira LG, Monte-Alto-Costa A. Selective inhibition of COX-2 improves cutaneous wound healing of pressure ulcers in mice through reduction of iNOS expression. Life Sci 2016;153:82-92.

31. Neve A, Cantatore FP, Maruotti N, Corrado A, Ribatti D. Extracellular matrix modulates angiogenesis in physiological and pathological conditions. Biomed Res Int 2014;2014:756078.

32. Birkenhauer E, Neethirajan S. A double-edged sword: The role of VEGF in wound repair and chemoattraction of opportunist pathogens. Int J Mol Sci 2015;16:7159-72.

33. Baharfar R, Azimi R, Mohseni M. Antioxidant and antibacterial activity of flavonoid, polyphenol and anthocyanin-rich extracts from Thymus kotschyanus Boiss and Hohen aerial parts. J Food Sci Technol 2015;52:6777-83.

34. Moallem SA, Imenshahidi M, Shahini N, Javan AR, Karimi M, Alibolandi M, et al. Synthesis, anti-inflammatory and anti- nociceptive activities and cytotoxic effect of novel thiazolidin-4-ones derivatives as selective cyclooxygenase (COX-2) inhibitors. Iran J Basic Med Sci 2013;16:1238-44.

35. Xue M, Jackson CJ. Extracellular matrix reorganization during wound healing and its impact on abnormal scarring. Adv Wound Care (New Rochelle) 2015;4:119-36.

36. Habibipour S, Oswald TM, Zhang F, Joshi P, Zhou XC, Dorsett-Martin W, et al. Effect of sodium diphenylhydantoin on skin wound healing in rats. Plast Reconstr Surg 2003;112:1620-7.

37. Lademann J, Vergou T, Darvin ME, Patzelt A, Meinke MC, Voit $\mathrm{C}$, et al. Influence of topical, systemic and combined application of antioxidants on the barrier properties of the human skin. Skin Pharmacol Physiol 2016;29:41-6.

38. Guo S, Dipietro LA. Factors affecting wound healing. J Dent Res 2010;89:219-29. 